\title{
ZAWARCIE MAŁŻEŃSTWA KANONICZNEGO I CYWILNEGO W PRAWIE HISZPAŃSKIM - ZARYS PERSPEKTYWY HISTORYCZNEJ
}

Contracting a canonical and civil marriage in Spanish law: A historical perspective

Streszczenie: Tematem niniejszego artykułu jest możliwość zawierania małżeństwa kanonicznego i cywilnego w Hiszpanii od czasów królów katolickich Izabeli i Ferdynanda do współczesnej monarchii konstytucyjnej. Analizę rozpoczyna omówienie możliwości zawierania małżeństwa kanonicznego w katolickiej monarchii Habsburgów. Drugim wyróżnionym w opracowaniu okresem historycznym jest okres I Republiki, w której to prawodawca, tworząc fundamenty świeckiego państwa, po raz pierwszy usiłował wprowadzić do prawa hiszpańskiego instytucję małżeństwa cywilnego. W kolejnych trzech wyróżnionych okresach historycznych, tj. restauracji burbońskiej, II Republice i Hiszpanii pod rządami gen. Franco, w tekście artykułu analizowane są przepisy umożliwiające i ograniczające możliwość zawarcia małżeństwa kanonicznego i cywilnego. Uważny czytelnik dostrzeże, że przepisy te tworzone były nie tyle z perspektywy prawa do zawarcia małżeństwa zgodnie z posiadanymi przez konkretną osobę przekonaniami (perspektywa prawa prywatnego), ile raczej ze zmieniającej się dynamicznie perspektywy ustrojowej w zakresie relacji państwo-Kościół (perspektywa prawa publicznego). Podejście to hiszpański prawodawca porzucił dopiero w okresie współczesnej nam monarchii konstytucyjnej.

Słowa kluczowe: zawarcie małżeństwa; małżeństwo kanoniczne; małżeństwo cywilne; małżeństwo w Hiszpanii; kanoniczna forma zawarcia małżeństwa

* Ks. dr hab., prof. UKSW, Katedra Prawa Wyznaniowego i Komparatystyki Prawniczej, Instytut Prawa Kanonicznego, Uniwersytet Kardynała Stefana Wyszyńskiego, ul. Dewajtis 5, 01-815 Warszawa, e-mail: p.rygula@uksw.edu.pl. ORCID 0000-0003-1716-2789. 
Abstract: The present paper focuses on the possibilities of contracting a canonical and civil marriage in Spain in the period from the rule of the Catholic Monarchs, Isabella and Ferdinand, to the present-day constitutional monarchy. The analysis begins with a discussion of the possibilities of contracting a canonical marriage in the Catholic Habsburg Monarchy. The second historical period examined in the paper is the First Spanish Republic, when the legislator, laying foundations of a civil state, attempted to introduce the institution of civil marriage to Spanish law for the first time. When it comes to the subsequent three historical periods, the Bourbon Restoration, the Second Spanish Republic, and General Franco's Spain, the paper analyses the regulations that either enabled or limited the possibility to contract a canonical and civil marriage. A careful reader will notice that those regulations were not created from the perspective of the right to contract a marriage, which corresponds to a specific person's convictions (the perspective of private law), but from the dynamically changing perspective of state-church relations in the political system (the perspective of public law). That approach was abandoned by the Spanish legislator only in the times of the present-day constitutional monarchy.

Key words: contracting a marriage; canonical marriage; civil marriage; marriage in Spain; canonical form of contracting a marriage

\section{WPROWADZENIE}

Zawarcie małżeństwa kanonicznego i cywilnego w Hiszpanii z perspektywy historycznej mogłoby z pewnością stać się przedmiotem opracowania w formie monografii. Niezwykle interesującym byłoby prześledzenie tego zagadnienia od momentu powstania wspólnoty politycznej określanej dzisiaj mianem Hiszpanii do czasów nam współczesnych, analizując nie tylko samą formę zawierania małżeństwa na przestrzeni wieków, ale także zmiany, jakie zachodziły w pojmowaniu instytucji małżeństwa, w tym wyłonienie się instytucji małżeństwa cywilnego (po wcześniejszym wypracowaniu idei rozdziału państwo-Kościół). Zdając sobie sprawę z wagi tematu i równocześnie z niewielkiej pozycji literatury w języku polskim na powyższy temat, niniejsze opracowanie ma na celu przynajmniej częściowe zapełnienie tej luki. Szczególnie interesującym przedmiotem analizy w niniejszym i w przyszłych opracowaniach - wydaje się być wpływ przemian społeczno-polityczno-kulturowych na kształtowanie się rozumienia 
instytucji małżeństwa, w tym na sposób jego zawierania. Zakres czasowy niniejszego opracowania wyznaczają zasadniczo dwa akty prawne: rozporządzenie królewskie (cédula real) Filipa II z dnia 12 lipca 1564 r., za pomocą którego do ustawodawstwa hiszpańskiego włączony został soborowy dekret Tametsi oraz hiszpańska ustawa z dnia 2 lipca 2015 r. o jurysdykcji w postępowaniu nieprocesowym (Ley de la Jurisdicción Voluntaria ${ }^{1}$.

\section{FORMA ZAWARCIA MAŁŻEŃSTWA W HISZPANII DO CZASU I REPUBLIKI HISZPAŃSKIEJ}

Od czasu, kiedy chrześcijaństwo stało się religią dominującą w Europie, w tym także na Półwyspie Iberyjskim, właściwe dla tej religii rozumienie instytucji małżeństwa na wiele stuleci zdominowało praktykę życia małżeńskiego na Starym Kontynencie. Znalazło to swoje odzwierciedlenie m.in. w jurysdykcji Kościoła nad małżeństwem. Zmiana postrzegania rzeczonej instytucji prawnej w Europie nastąpiła w czasach nowożytnych wraz z nadejściem reformacji, w ramach której odrzucano koncepcję małżeństwa jako sakramentu. Wspominając zmianę świadomości społecznej i prawnej Europejczyków w powyższym zakresie, należy jednak pamiętać, że recepcja ruchu reformatorskiego i jego idei nie wszędzie była jednakowa.

W przeciwieństwie do znacznego terytorium Starego Kontynentu, na którym reformacja zdominowana była przez myśl protestancką, w hiszpańskich posiadłościach monarchii Habsburgów piętnastowieczna reforma chrześcijaństwa zainicjowana została i przeprowadzona wewnątrz wspólnoty katolickiej. Jej inicjatorami byli zarówno wybitni przedstawiciele Kościoła Rzymskokatolickiego (np. abp Toledo Francisco Cisneros), jak i monarchii (począwszy od pary królewskiej Izabeli i Ferdynanda po Filipa II Habsburga) ${ }^{2}$. Powiązanie reformy - tak po stronie katolickiej, jak

Ley 15/2015, de 2 de julio, de la Jurisdicción Voluntaria, BOE 2015, n. 158 (de 3 de julio), s. 54068-54201.

2 Wykorzystując udział abp. Toledo Alfonsa Carilla w działaniach zbrojnych przeciwko królowej Izabeli, królowie katoliccy wymusili na przedstawicielach Kościoła hiszpańskiego zebranych na synodzie w Sewilli w 1478 r. zgodę na przeprowadzenie licznych reform wewnątrz wspólnoty katolickiej na terytorium ich monarchii. Wspomniane reformy, 
i protestanckiej - z władzami państwa skutkowało dążeniem wspomnianych władz do wpisania ,własnego" Kościoła w ramy ustrojowe nowożytnych monarchii. Proces ten widoczny był w nowo powstających państwach protestanckich. Z pewnym wyprzedzeniem czasowym podobny skutek odniosła także reforma Kościoła Katolickiego w Hiszpanii ${ }^{3}$. W ten sposób narodził się system jurysdykcjonalizmu, który swoją nazwę bierze od poddania Kościoła jurysdykcji państwa. W przypadku jurysdykcjonalizmu katolickiego, nie negując uniwersalnego charakteru Kościoła Katolickiego, na terytorium własnego państwa władcy traktowali go jako instytucję narodową. Widać to bardzo wyraźnie w działaniach Izabeli i Ferdynanda, a w jeszcze większym stopniu Filipa II, dążącego do ukształtowania Kościoła na wzór instytucji ,państwowo-narodowej”, która, za pomocą osób zaufanych z perspektywy interesów państwa, wspiera monarchię w zakresie administracji, polityki, finansów ${ }^{4}$.

W odpowiedzi na wysuniętą przez Kościoły reformowane koncepcję instytucji małżeństwa, Kościół Katolicki wypracował w czasie Soboru Trydenckiego (1545-1563) argumenty w obronie katolickiej doktryny, którą to zawarł w postanowieniach dekretu Tamesti. Uchwalony 11 listopada 1563 r. dokument soborowy określał m.in. obowiązkową formę zawarcia małżeństwa kanonicznego, od przestrzegania której uzależniał ważność zawieranego związku5. Należy jednak pamiętać, że dekret ten, przegłosowany na soborze przy znacznej liczbie głosów przeciwnych, uzyskiwał moc obowiązującą na danym terytorium dopiero w momencie jego promulgacji przez właściwą temu terytorium władzę świecką .

doprowadzając do wyraźnego uniezależnienia się tego Kościoła od Stolicy Apostolskiej, zakończone zostały za rządów Filipa II, którego politykę wyznaniową historycy określają jako „ortodoksyjny nacjonalizm katolicki”. Ryguła 2009b, 30-31. Por. Payne 2006, 67-68.

3 J. Krukowski słusznie stwierdza w powyższym temacie: „Władcy katoliccy, idąc za przykładem protestanckich, rościli sobie władzę nad Kościołem w swoim kraju”. Krukowski 2000, 34-39. Z tak ustawionej perspektywy czasowej wymyka się wspomniana wyżej Hiszpania, która jako jedyny kraj katolicki wprowadzała system jurysdykcjonalizmu nieco wcześniej od państw protestanckich.

4 Ryguła 2009b, 31.

5 Dziadzio 2011, 311.

6 Przez ponad trzysta lat, na tzw. terytoriach nietrydenckich, pokrywających się w dużej mierze z państwami protestanckimi, dekret ten nigdy nie został promulgowany. Dohnalik $2018,185$. 
W Hiszpanii na mocy rozporządzenia królewskiego (cédula real) Filipa II z dnia 12 lipca 1564 r., dekrety Soboru Trydenckiego, w tym dekret Tametsi, włączone zostały w ramy ustawodawstwa hiszpańskiego ${ }^{7}$. W ten sposób hiszpańska korona uznawała kompetencje Kościoła Katolickiego w zakresie doktryny i ustawodawstwa małżeńskiego, zachowując dla siebie możliwość stanowienia przepisów odnośnie do skutków cywilnych ważnie zawartych małżeństw oraz zakazów ich zawierania. Powyższa decyzja Filipa II stała się fundamentem systemu obowiązkowego małżeństwa religijnego, który przetrwał w Hiszpanii ponad 300 lat, tj. do powstania I Republiki (1564-1870).

W zgodzie z powyższym pozostaje brak jakiegokolwiek zapisu dotyczącego małżeństwa, w tym także sposobu jego zawierania, w konkordacie z 1851 r. $^{8}$, którego to ustalenia pozostawały w mocy do czasu utworzenia II Republiki (1931 r.). Brak ten - pisze A. de la Hera - wydaje się oczywisty, jako że decyzja przekazania jurysdykcji nad małżeństwem Kościołowi w rozporządzeniu królewskim Filipa II była jednostronnym, autonomicznym aktem władzy monarchy. Brak zapisu konkordatowego odnośnie do jurysdykcji nad małżeństwem, będącego jakże często przedmiotem dwustronnych uzgodnień w późniejszych umowach konkordatowych, potwierdzał ten stan rzeczy, tj. jednostronną jurysdykcję władzy państwowej w powyższym zakresie ${ }^{9}$. Przejawem tej władzy było rozporządzenie królewskie Filipa II, który na mocy wspomnianego wyżej aktu władzy świeckiej recypował przepisy dekretu Tametsi w ramy prawa hiszpańskiego. Biorąc zaś pod uwagę temat niniejszego opracowania trzeba stwierdzić, że dokonując recepcji przepisów soborowych do prawa monarchii, Filip II nie tyle gwarantował, ile raczej obligował ochrzczonych w Kościele Katolickim do zawierania małżeństwa zgodnie z formą kanoniczną.

Duża część autorów dwudziestowiecznej doktryny prawa wyznaniowego wskazuje, że reformacja katolicka, jaka dokonała się w Hiszpanii,

7 We wspomnianym wyżej dekrecie monarcha stwierdzał: „Aceptamos y recibimos el dicho sacrosanto concilio y queremos que en estos nuestros reinos sea guardado, cumplido y ejecutado”. Cyt. za: Fernández Collado 2007, 211.

8 Zapisów dotyczących małżeństwa nie zamieszczano także w poprzednich umowach konkordatowych, uznając to za niekonieczne wobec obowiązywania dekretu Tametsi na terytorium hiszpańskim.

9 De la Hera 1975, 642-643. 
wyprzedzając czasowo reformację protestancką, skutkowała m.in. zachowaniem w społeczeństwie hiszpańskim dotychczasowego wyobrażenia o małżeństwie, także w jego wymiarze religijnym ${ }^{10}$. Pojedyncze, odmienne opinie dotyczące ówczesnego rozumienia i praktyki życia małżeńskiego wydają się niezgodne z rzeczywistością, zarówno tą sprzed, jak i po wejściu w życie wspomnianego rozporządzenia królewskiego Filipa II. Wspomnieć można tutaj pogląd F. Sáncheza Romána, który utrzymywał, że „od momentu ukonstytuowania się Hiszpanii jako wspólnoty narodowej z własną historią i prawem, tj. od początku V stulecia aż do wieku XVI, kiedy to Filip II wprowadził jako państwowe prawo małżeńskie trydencką reformę prawa, można powiedzieć, że współistniały obok siebie cywilna i religijna forma małżeństwa; a co za tym idzie, że zachowywano w prawie hiszpańskim kategorię małżeństwa świeckiego"11. Lektura całego tekstu F. Sáncheza Romána wskazuje, że Autor ten zakłada, jakoby we wspomnianym przez niego okresie historycznym istniały małżeństwa (w tym katolików), które, ze względu na zawarcie ich nie według formy liturgicznej, nie były małżeństwami kanonicznymi ${ }^{12}$.

Z powyższym poglądem nie zgadzają się m.in. A. Fuenmayor ${ }^{13}, \mathrm{R}$. Navarro Valls ${ }^{14}$ czy A. de la Hera ${ }^{15}$. Ostatni z wymienionych Autorów, odnosząc się do cytowanego fragmentu monografii F. Sáncheza Romána, zauważa, że błąd w nim zawarty wynika z założenia, jakoby forma zawarcia małżeństwa determinowała cywilną lub kanoniczną naturę samego związku małżeńskiego. Istnieją autorzy - pisze A. de la Hera - którzy zakładają, że związek małżeński niezawarty w formie przewidzianej prawem

10 Pérez Mier 1963, 297.

11 Sánchez Román 1912, 408. Wszystkie thumaczenia z jęz. hiszp. zawarte w niniejszym artykule są tłumaczeniami jego Autora.

12 A. Tunia pisze, cytując tekst J. S. Pelczara: „W średniowieczu w prawie kościelnym nie było jakiejś obowiązkowej formy zawarcia małżeństwa, która obowiązywałaby strony wstępujące w związek małżeński pod rygorem nieważności. Wystarczające było to, gdy «narzeczeni w dowolny sposób przed kapłanem i w obecności świadków, bądź także bez kapłana i bez świadków wyrazili sobie zgodę na wzajemne pożycie małżeńskie»”. Tunia 2008, 132; Pelczar 1898, 10.

13 Fuenmayor 1963, 291.

14 Navarro Valls 1972, 221-222.

15 De la Hera 1975, 640-642. 
kanonicznym oznacza zawarcie małżeństwa niekanonicznego. Nie biorą oni jednak pod uwagę faktu, że do momentu wprowadzenia przez Sobór Trydencki wymogu zawarcia małżeństwa kanonicznego zgodnie z formą przewidzianą prawem, niezachowanie stosowanej wówczas formy liturgicznej nie wpływało na nieważność związku kanonicznego, implikując jedynie niegodziwy sposób jego zawierania ${ }^{16}$.

Kanoniczność małżeństwa wynika bowiem - kontynuuje A. de la Hera - nie z faktu zawarcia go w formie przewidzianej przez prawo kanoniczne, bo taka forma może przecież nie być obowiązkowa w danym okresie historycznym, a nawet gdy uznana jest za obowiązkową, konkretne osoby mogą zawrzeć małżeństwo kanoniczne z dyspensą od wspomnianej formy. Nie wynika też z sakramentalnego charakteru małżeństwa, bo przecież nie zawsze małżeństwo kanoniczne jest sakramentem ${ }^{17}$. Kanoniczność konkretnego małżeństwa, a co za tym idzie jurysdykcja Kościoła w tym zakresie, wynika z faktu przyjęcia chrztu przez osoby wstępujące w związek małżeński, a w konsekwencji z faktu przynależności tych osób do Kościoła w momencie zawierania małżeństwa ${ }^{18}$. Stąd niejednokrotnie, szczególnie w okresie przed wejściem w życie dekretu Tametsi, osoby należące do Kościoła zawierały małżeństwo z pominięciem formy liturgicznej, co nie jest równoznaczne z zawarciem przez nie małżeństwa niekanonicznego ${ }^{19}$, tym bardziej cywilnego w rozumieniu współczesnego nam prawa ${ }^{20}$.

$\mathrm{Z}$ drugiej strony dużym uproszczeniem jest twierdzenie - pomimo że istnieją autorzy głoszący taką tezę - jakoby małżeństwa niekanoniczne, zarówno przed, jak i po wejściu w życie dekretu Tametsi, nie były uznawane na terytorium monarchii hiszpańskiej jako w pełni legalne związki małżeńskie ${ }^{21}$. Nauki historyczne wykazują, że nadal, przez wiele wieków po pojawieniu się na Półwyspie Iberyjskim chrześcijaństwa, pozostawały w użyciu na wspomnianym terytorium niechrześcijańskie, religijne formy

16 Tamże, 641.

17 Bernárdez Cantón 1971, 40.

18 Dla tych osób prawo kanoniczne, także współcześnie, przewiduje możliwość zawarcia małżeństwa w różnych formach, w tym także w formie cywilnej. De la Hera 1975, 641.

19 Acuña Guirola 1973, 137-190.

20 De la Hera 1975, 642.

21 Rodríguez Chacón 1994, 371. 
zawierania związku małżeńskiego. Z biegiem czasu wspomniane obrzędy zanikały, a obok dominującej formy związanej z chrześcijaństwem w użyciu pozostały formy zawierania małżeństwa wywodzące się z religii mojżeszowej i islamu.

W związku z polityką wyznaniową prowadzoną przez monarchów hiszpańskich, zarówno przed, jak i po wprowadzeniu w życie przepisów dekretu Tametsi do prawodawstwa hiszpańskiego, można spotkać akty prawne utrudniające lub nawet zakazujące wspomnianym wyżej dwóm mniejszościowym grupom wyznaniowym zawierania małżeństwa według własnego rytu religijnego. Przykładem niech będzie przepis zawarty w zbiorze praw tzw. Fuero Juzgo, zakazujący Żydom zawarcia małżeństwa zgodnie z ich własnym prawem religijnym ${ }^{22}$. Dla współczesnych badaczy nie jest jednak oczywistym, czy zakaz ten dotyczył Żydów w rozumieniu grupy etnicznej czy religijnej, a więc tylko tych, którzy nie przeszli na chrześcijaństwo, pozostając przy wierze mojżeszowej ${ }^{23}$. Jaśniejsze dla współczesnych badaczy są przepisy uznające ważność małżeństw niechrześcijan zawieranych zgodnie z ich własnymi przepisami religijnymi. Przykładem może być tutaj przepis uznający legalność małżeństw zawieranych między wyznawcami religii mojżeszowej oraz między wyznawcami islamu, zamieszczony w zbiorze praw tzw. Las Siete Partidas ${ }^{24}$.

Studium J. A. De Jorge García Reyesa wykazuje, że w średniowiecznej Hiszpanii wyznawcy chrześcijaństwa, religii mojżeszowej i islamu zasadniczo uznawali wzajemnie małżeństwa zawierane wewnątrz wspomnianych trzech religii, zgodnie z normami dla każdej z nich właściwymi. Nie czynili tego oczywiście w imię nieznanej ówczesnym idei wolności religijnej, której przestrzegania chroniłyby przepisy stanowione przez prawodawcę państwowego, ale z pobudek pragmatycznych, będących fundamentem

22 Wspomniany zakaz zawarto w księdze XII, tytule II, rubryce 2 zbioru Fuero Juzgo. Zob. Fuero Juzgo de Juan de la Reguera Valdelomar, 1798, BOE (Leyes Históricas de España), Madrid 2015, s. 271.

23 Rodríguez Chacón 1994, 372.

24 Wspomniany wyżej przepis znajduje się w księdze IV (Partida IV), tytule VII (Título VII), prawie II (Ley II) zbioru praw Las Siete Partidas, opracowany po raz pierwszy za rządów Alfonsa X Mądrego, władcy Kastylii i Leonu (1252-1284), w celu wprowadzenia jednolitego zbioru praw dla całego królestwa. Tekst zbioru: Las Siete Partidas, BOE (Colección: Textos Históricos), Madrid 2011. 
pokojowego współistnienia wspomnianych religii ${ }^{25}$. Niewiele w tej materii zmieniło rozporządzenie królewskie Filipa II z dnia 12 lipca 1564 r., za pomocą którego w ramy ustawodawstwa hiszpańskiego włączono przepisy dekretu Tametsi. Przepisy te obowiązywały bowiem ad validatem matrimonii jedynie osoby ochrzczone ${ }^{26}$.

\section{OKRES I REPUBLIKI (1873-1874)}

Jak wspomniano wyżej, brak jakiegokolwiek bilateralnego uzgodnienia dotyczącego małżeństwa w konkordacie z 1851 r. stanowił potwierdzenie stanu prawnego wprowadzonego w życie rozporządzeniem królewskim Filipa II z 1564 r., recypującym regulacje Soboru Trydenckiego w zakresie małżeństwa w ramy prawa hiszpańskiego. Równocześnie - pisze wspomniany już A. de la Hera - stanowił uznanie po obu stronach, że jurysdykcja w zakresie podtrzymania skutków prawnych wynikających ze wspomnianego rozporządzenia lub też zmiany legislacji w powyższym zakresie pozostaje po stronie państwa ${ }^{27}$. Można chyba jednak domniemywać, że strony zawieranej w połowie XIX w. umowy konkordatowej nie przewidywały, iż w wyniku przemian społeczno-politycznych źródłem prawa w przyszłości będzie prawodawca republikański, dążący do zbudowania nowego ustroju na zasadzie negacji aksjologicznych podstaw ustrojowych monarchii.

Odchodząc od obowiązkowej formy zawarcia małżeństwa in facie Ecclesiae, prawodawca państwowy już 1870 r. - tj. w okresie rządu tymczasowego (1868-1871), bezpośrednio poprzedzającym proklamowanie I Republiki - usiłował wprowadzić system obowiązkowego małżeństwa cywilnego. W art. 2 ustawy tymczasowej z dnia 18 czerwca $1870 \mathrm{r}^{28}$ prawodawca ten stwierdzał, że zawarcie małżeństwa niezgodne z przepisami zawartymi w rzeczonej ustawie nie powoduje zaistnienia skutków

25 De Jorge García Reyes 1986, 50 i nn.

26 Rodríguez Chacón 1994, 372-374.

27 De la Hera 1975, 643.

28 Ley provisional de matrimonio civil, ,Gaceta de Madrid” 1870, n. 172 (de 21 de junio), s. 1-2. 
cywilnych. Nie zabraniając zawarcia małżeństwa kanonicznego, nie uznawał on jednak skutków cywilnych w stosunku do małżeństw zawieranych wyłącznie w formie religijnej. Art. 28 ustawy zobowiązywał osoby pragnące, aby ich związek zaistniał w obrocie cywilnoprawnym, do zawarcia małżeństwa wobec właściwego sędziego municypalnego oraz dwóch pełnoletnich świadków.

Wspominając ustawę z 1870 r. należy odnotować, że powstała ona jako ustawa tymczasowa, w trakcie gorącej debaty na forum Kortezów Generalnych dotyczącej projektu nowego kodeksu cywilnego. W związku z niemożnością ukończenia prac legislacyjnych nad tekstem kodeksu, ówczesny Minister Sprawiedliwości, Eugenio Montero Ríos, doprowadził do wprowadzenia w Hiszpanii (po raz pierwszy w historii) instytucji małżeństwa cywilnego w trybie rzeczonej ustawy. W związku z powyższym ustawa ta regulowała nie tylko formę zawarcia tego związku, ale także wiele innych kwestii związanych ze wspomnianą instytucją prawa małżeńskiego.

Warto w tym miejscu nadmienić o podobieństwach w treści konkretnych przepisów zawartych we wspomnianym akcie prawnym do treści przepisów kanonicznych regulujących małżeństwo kanoniczne. Dla przykładu wspomnieć można art. 1 ustawy państwowej z 1870 r., w której stwierdza się, że „małżeństwo ze swej natury jest związkiem trwałym i nierozerwalnym" oraz art. 5 ust. 2 tejże ustawy, w którym za niezdolnych do zawarcia małżeństwa cywilnego uznaje się katolików, którzy przyjęli święcenia lub złożyli wieczysto-publiczny ślub czystości, chyba że jedni lub drudzy uzyskali właściwą dyspensę kanoniczną. Wprowadzając instytucję rozwodu do hiszpańskiego prawa małżeńskiego w art. 86 ustawa gwarantuje go tylko „niewinnemu małżonkowi”. W art. 83 z kolei, determinując jego naturę, prawodawca pozostaje w zgodzie z art. 1 ustawy i stwierdza, że rozwód (divorcio) „nie rozwiązuje małżeństwa, zawieszając jedynie wspólnotę życia małżonków i jej skutki”. W związku z powyższym, istnieją autorzy wyrażający opinię, z którą nie mogę się w pełni zgodzić, jakoby małżeństwo cywilne regulowane przepisami ustawy z $1870 \mathrm{r}$. nie stanowiło odrębnej kategorii w stosunku do obecnego wcześniej w hiszpańskim systemie prawnym małżeństwa kanonicznego, a jedynie wprowadzało cywilną formę zawarcia związku małżeńskiego ${ }^{29}$.

29 Martí, García-Pardo, Catalá 2003, 48-49. 


\section{RESTAURACJA BURBOŃSKA (1874-1931)}

Po rewolucyjnym sześcioleciu, w Hiszpanii wprowadzono nowy system prawa małżeńskiego, który po raz pierwszy w historii tego państwa przewidywał współistnienie obok siebie ,dwóch form małżeństwa” (dos formas del matrimonio): kanonicznego i cywilnego. System ten przetrwał niezmieniony w swoim zasadniczym kształcie do upadku monarchii i narodzin II Republiki ${ }^{30}$. Oparty został on na fundamentalnych założeniach tworzonego w tym czasie nowego systemu prawa cywilnego, zawartego w ustawie z dnia 11 maja 1888 r. $^{31}$ Rok później ten nowy system prawa małżeńskiego wpisany został w regulacje kodeksu cywilnego, opublikowanego w „Gaceta de Madrid” ${ }^{2}$. W art. 42 kodeksu prawodawca hiszpański uznawał „dwie formy małżeństwa: kanoniczną, którą powinny zawierać wszystkie osoby wyznające religię katolicką, oraz cywilną, która zawierana będzie zgodnie z przepisami tego kodeksu". Dopełniając treść cytowanego przepisu, w stosunku do małżeństwa kanonicznego w art. 75 prawodawca stwierdzał: „Wymogi, forma i ceremonie zawarcia małżeństwa kanonicznego regulowane są przepisami Kościoła katolickiego i Soboru Trydenckiego, uznanymi jako ustawy królestwa". Z kolei w art. 76 deklarował, że zawarcie takiego małżeństwa ,pociąga za sobą zaistnienie skutków cywilnych w stosunku do małżonków i posiadanych przez nich dóbr oraz ich potomstwa".

Samą formę zawarcia małżeństwa kanonicznego kodeks regulował w art. 77, w którym stwierdzało się: „W akcie zawarcia małżeństwa kanonicznego uczestniczyć będzie sędzia municypalny lub inny urzędnik państwowy, tylko po to, aby dokonać natychmiastowego wpisu do rejestru cywilnego. W tym celu, zawierający małżeństwo winni powiadomić na piśmie trybunał właściwego municypium z wyprzedzeniem co najmniej dwudziestu czterech godzin, informując o godzinie, dniu i miejscu,

30 Wspomniany czasookres, który cechował się dużą stabilnością życia społeczno-politycznego określany jest w historii Hiszpanii mianem restauracji burbońskiej.

${ }^{31}$ Ley autorizando al Gobierno para publicar un Código civil con arreglo á las condiciones y bases que se establecen en esta ley, „Gaceta de Madrid”1888, n. 143 (de 22 de mayo), s. 565-567.

32 Real Decreto de 24 de julio de 1889 por el que se publica el Código Civil, „Gaceta de Madrid" 1889, n. 206 (de 25 de julio), s. 249 i nn. 
w którym zawierane będzie małżeństwo". W cytowanym artykule prawodawca zobowiązywał ponadto sędziego do wydania narzeczonym potwierdzenia o otrzymanym powiadomieniu ${ }^{33}$, a właściwemu proboszczowi zabraniał celebracji małżeństwa, gdyby ten nie otrzymał wspomnianego potwierdzenia.

W cytowanym wyżej art. 42 hiszpańskiego kodeksu cywilnego, o formie zawierania małżeństwa kanonicznego lub cywilnego decydował fakt wyznawania religii katolickiej (profesar la religión católica). Termin ten, zawarty w przepisie uchylonym dopiero ustawą z dnia 7 lipca 1981 r. $^{34}$, stał się więc przedmiotem licznych interpretacji na polu prawa administracyjnego i orzecznictwa w okresie prawie stu lat pozostawania w mocy wspomnianego przepisu ${ }^{35}$. Wątpliwości w aplikacji tego artykułu budziła nie tylko właściwa wykładnia wyrażenia profesar la religión católica, ale także to, czy obowiązek zawarcia małżeństwa kanonicznego powstaje w sytuacji, gdy religię tę wyznają oboje narzeczeni czy wystarczy, że wyznaje ją jedno $\mathrm{z}$ nich ${ }^{36}$. Podstawową trudność w wykładni terminu „wyznawać wiarę katolicką" stanowiło jednak pytanie: czy rzeczone wyznawanie wiary prawodawca uznaje za równoważne z formalną przynależnością do Kościoła Katolickiego na skutek przyjętego wcześniej chrztu czy też ma on na myśli aktualny stan wiary osoby pragnącej zawrzeć małżeństwo?

33 Niepowiadomienie właściwego sędziego przez narzeczonych zagrożone było karą mandatu w wysokości 5-80 peset. Wspomniany art. 77 stwierdza ponadto:

„Jeśli małżeństwo zostałoby zawarte bez udziału sędziego municypalnego lub jego delegata, pomimo że został on powiadomiony przez kontrahentów, pokryje on koszty związane z wpisem małżeństwa do rejestru cywilnego, i obciążony zostanie dodatkowo mandatem w wysokości od 20 do 100 peset. W powyższym wypadku uznaje się zaistnienie skutków cywilnych małżeństwa od momentu celebracji jego zawarcia.

Jeśli kontrahenci nie powiadomiliby sędziego municypalnego, mogą oni zwrócić się z prośbą o wpisanie małżeństwa do rejestru cywilnego. W takim wypadku uznaje się zaistnienie skutków cywilnych tego małżeństwa od momentu jego wpisu".

${ }^{34}$ Ley 30/1981, de 7 de julio, por la que se modifica la regulación del matrimonio en el Código Civil y se determina el procedimiento a seguir en las causas de nulidad, separación $y$ divorcio, BOE 1981, n. 172 (de 20 de julio), s. 16457-16462.

35 Ryguła 2009a, 142.

36 De la Hera 1975, 643. 
W kierunku tego drugiego rozumienia treści art. 42 hiszpańskiego kodeksu cywilnego, a więc w kierunku odejścia od literalnej wykładni, obligującej do zawarcia małżeństwa kanonicznego wszystkich wyznających formalnie religię katolicką, skłaniało się rozporządzenie Ministra Sprawiedliwości z dnia 28 grudnia 1900 r. ${ }^{37}$ Umożliwiało ono zawarcie małżeństwa cywilnego, jeśli przynajmniej jeden z kontrahentów (na podstawie wypisu z rejestru kościelnego lub na drodze zaprzysiężonego oświadczenia przed przedstawicielem właściwej władzy państwowej) wykaże, że nie wyznaje tej religii ${ }^{38}$. Bezpośrednio do wspomnianego rozporządzenia ministerialnego z 1900 r. nawiązywało rozporządzenie królewskie z mocą ustawy z dnia 27 sierpnia 1906 r. ${ }^{39}$ Poszerzając zakres osobowy dopuszczonych do zawarcia związku cywilnego, prawodawca nie tylko zezwalał w nim na zawarcie tego małżeństwa w sytuacji, gdy jeden z kontrahentów nie wyznawał religii katolickiej, ale dopuszczał także do jego zawarcia nie wymagając żadnej deklaracji odnośnie do religii wyznawanej przez kontrahentów. W ten sposób na krótki okres wprowadzono w Hiszpanii system fakultatywnego małżeństwa cywilnego, umożliwiając - pomimo pozostawania w mocy art. 42 hiszpańskiego kodeksu cywilnego - zawieranie małżeństwa cywilnego przez katolików, którzy w czasie podejmowania decyzji o zawarciu małżeństwa nie chcieli zawrzeć związku kanonicznego ${ }^{40}$.

Ze względu na negatywną reakcję dużej części społeczeństwa hiszpańskiego na wprowadzone prawo oraz zarzut, że wspomniane rozporządzenie królewskie pozostaje w sprzeczności z przepisami

37 Dirección general de los Registros civil y de la propiedad y del Notariado.- Orden de esta Dirección resolviendo que no há lugar á la pretensión formulada ante ese Centro directivo por D. J. P. V., „Gaceta de Madrid” 1901, n. 67 (de 8 de marzo), s. 1001.

38 Martí, García-Pardo, Catalá 2003, 50.

39 Real orden resolviendo que no se exija á los que pretendan contraer matrimonio civil, conforme á los artículos 86, 89 y siguientes del Código civil, declaración alguna relativa á la religión que profesen, „Gaceta de Madrid” 1906, n. 240 (de 28 de agosto), s. 830-831.

40 Dla zobrazowania, w mieście Zamora z możliwości zawarcia małżeństwa cywilnego zgodnie z powyższym rozporządzeniem ministerialnym - do czasu, kiedy taka możliwość zaistniała - skorzystały dwie pary katolików. Są to dwa pierwsze małżeństwa cywilne katolików wpisane do rejestru cywilnego Zamory. Obie pary zawarły w krótkim czasie małżeństwa kanoniczne. Zob. Hernández Fuentes 2016, 306. 
kodeksu cywilnego ${ }^{41}$, już pół roku później, rozporządzeniem królewskim z dnia 28 lutego 1907 r. powrócono do stanu prawnego wprowadzonego rozporządzeniem Ministra Sprawiedliwości z dnia 28 grudnia 1900 r., domagając się od osób pragnących zawrzeć małżeństwo cywilne wykazania przynajmniej przez jedną z nich niewyznawania religii katolickiej ${ }^{42}$.

Pięć lat później, także w trybie rozporządzenia królewskiego (z dnia 28 czerwca 1913 r.) (3) $^{43}$ dokonano wykładni art. 42 hiszpańskiego kodeksu cywilnego uznając za obowiązujący stan prawny wprowadzony rozporządzeniem ministerialnym z 1900 r. Wykładnia ta była powszechnie akceptowana i aplikowana aż do upadku monarchii burbońskiej i narodzin II Republiki hiszpańskiej w 1936 r. ${ }^{44}$ Zgodnie z wykładnią zawartą w rozporządzeniu z 1913 r., małżeństwo cywilne mogły zawrzeć dwie osoby płci przeciwnej, z których przynajmniej jedna nie wyznawała religii katolickiej. Mogła to być osoba nieochrzczona w Kościele Katolickim albo deklarująca niewyznawanie katolicyzmu na podstawie rejestru kościelnego czy własnego oświadczenia. Rozporządzenie królewskie nie tylko uznawało wspomniane oświadczenie za wystarczające, ale wręcz nie dopuszczało możliwości przedstawienia dowodu przeciwnego ${ }^{45}$.

41 De la Hera 1975, 643-644.

42 Wspomniane rozporządzenie królewskie za nieobowiązujące uznawało rozporządzenie z dnia 27 sierpnia 1906 r., w którym to „deklaruje się wolność katolików w wyborze jednej z form małżeństwa dopuszczonych prawem". Real orden dejando sin efecto la de 27 de agosto último, por la que se dispone no se exija á los que pretendan contraer matrimonio civil declaración alguna relativa á la religión que profesen, y disponiendo que en los desacuerdos que puedan surgir entre Autoridades civiles y eclesiásticas sobre opción entre ambas formas de matrimonio, entrega de documentos, etc., ser oído el Fiscal de S. M. en la Audiencia del territorio en que se origine el conflicto, „Gaceta de Madrid” 1907, n. 60 (de 1 de marzo), s. 781-782.

43 Real Orden de 28 de junio de 1913 (sin título), „Gaceta de Madrid” 1913, n. 185 (de 4 de julio), s. 35.

44 De la Hera 1975, 645-646.

45 O ile doktryna prawa cywilnego wspomnianą wyżej deklarację niewyznawania katolicyzmu interpretowała jako przejaw aktualnego stanu wiary konkretnego człowieka, o tyle duża część kanonistów dopatrywała się w niej formalnej deklaracji braku przynależności do wspólnoty Kościoła Katolickiego (z wszystkimi tego konsekwencjami kanonicznymi). De la Hera 1975, 647. 
W katolickiej ustrojowo Hiszpanii ${ }^{46}$ w okresie restauracji burbońskiej pojawiła się więc tendencja stwarzania katolikom możliwości zawierania małżeństwa cywilnego ${ }^{47}$.

\section{II REPUBLIKA (1931-1939)}

W dniu 15 kwietnia 1931 r. - zaledwie jeden dzień po opuszczeniu kraju przez króla Alfonsa XIII i proklamowaniu przez rząd tymczasowy Republiki - opublikowano dekret zwany później Statutem prawnym Republiki. W art. 3 tegoż dekretu deklarowano: ,[...] państwo nigdy nie będzie mogło domagać się od obywatela wyjawienia jego przekonań religijnych"48. Przepis ten znalazł swoje odbicie w art. 27 Konstytucji republikańskiej z dnia 9 grudnia 1931 r. ${ }^{49}$, w którym ustrojodawca stwierdzał: „Nikt nie będzie zmuszany do deklarowania w sposób oficjalny swoich przekonań religijnych".

W sprzeczności z cytowanym wyżej dekretem i gwarancją konstytucyjną pozostawała treść art. 42 hiszpańskiego kodeksu cywilnego oraz wykładnia tegoż zawarta w rozporządzeniach królewskich z dnia 28 czerwca 1913 r. i 28 grudnia 1900 r. Przepisy te - pochodzące z okresu monarchii burbońskiej, ale pozostające nadal w mocy - stanowiły o konieczności stwierdzenia faktu wyznawania lub niewyznawania wiary katolickiej, od którego uzależniano możliwość zawarcia małżeństwa kanonicznego lub cywilnego. Ponadto konieczność reformy prawa małżeńskiego sugerował art. 43 republikańskiej ustawy zasadniczej, w którym prawodawca deklarował: „Rodzina znajduje się pod specjalną opieką państwa. Małżeństwo opiera się na równości praw obu płci, a jego rozwiązanie będzie możliwe

46 W art. 11 konstytucji hiszpańskiej z 1876 r. ustrojodawca uznawał katolicyzm za religię państwa, deklarując jednocześnie, że ,nikt nie będzie mógł być prześladowany na terytorium hiszpańskim ze względu na swoje poglądy". Constitución de la Monarquía Española, „Gaceta de Madrid” 1876, n. 184 (de 2 de julio), s. 9-12.

47 Ryguła 2009a, 143.

48 Decreto fijando el Estatuto jurídico del Gobierno, „Gaceta de Madrid” 1931, n. 105 (de 15 de abril), s. 195.

49 Constitución de la República Española, „Gaceta de Madrid” 1931, n. 344 (de 10 de diciembre), s. 1580. 
za obopólną zgodą albo na prośbę któregokolwiek z małżonków, z podaniem w tym przypadku właściwego powodu"50.

Reformę tę przeprowadzono stopniowo. Najpierw, rozporządzeniem Ministerstwa Sprawiedliwości z dnia 10 lutego 1932 r. ${ }^{51}$, wprowadzono odmienną od dotychczasowych interpretację art. 42 hiszpańskiego kodeksu cywilnego. W rozporządzeniu tym zniesiono wymóg wykazania przez osobę zamierzającą zawrzeć małżeństwo, że wyznaje lub nie wyznaje religię katolicką, uznając w ten sposób za nieobowiązujące rozporządzenie królewskie z 1900 r. Wprowadzony w trybie wspomnianego rozporządzenia ministerialnego z 1932 r. stan prawny w rzeczywistości odpowiadał stanowi wprowadzonemu już wcześniej (w latach 1906-1907) na mocy powołanego wyżej rozporządzenia królewskiego z mocą ustawy z dnia 27 sierpnia 1906 r. Zarówno wtedy, jak i w rozporządzeniu z dnia 10 lutego 1932 r. dopuszczano zawarcie cywilnego związku nie wymagając deklaracji odnośnie do religii wyznawanej przez kontrahentów. Oba rozporządzenia wprowadzały więc system fakultatywnego małżeństwa cywilnego, odchodząc od literalnej wykładni nieuchylonego formalnie art. 42 hiszpańskiego kodeksu cywilnego.

System obowiązkowego małżeństwa cywilnego prawodawca republikański wprowadził cztery miesiące później, ustawą z dnia 28 czerwca 1932 r. w której to za jedynie ważną na forum prawa państwowego uznawano cywilną formę zawarcia małżeństwa, dokonaną zgodnie $\mathrm{z}$ przepisami nowej ustawy ${ }^{52}$. Nie zabraniał on zawarcia małżeństwa in facie Ecclesiae, ale nie uznawał skutków cywilnych małżeństwa zawieranego zgodnie z formą kanoniczną. Ostateczny kształt republikańskiej reformy prawa małżeńskiego dopełniła normatywa zawarta w ustawie wprowadzającej do systemu prawa hiszpańskiego instytucję rozwodu.

50 Tamże.

51 Orden dictando normas relativas a la celebración del matrimonio civil, „Gaceta de Madrid" 1932, n. 32 (de 17 de febrero), s. 1182-1183.

52 Ley disponiendo que, a partir de la vigencia de la presente, sólo se reconocerá una forma de matrimonio, el civil, que deberá contraerse con arreglo a lo dispuesto en las Secciones primera y segunda, del capítulo tercero, del título cuarto, del Libro primero del Código civil, con las modificaciones que se insertan, „Gaceta de Madrid” 1932, n. 185 (de 3 de julio), s. 60. 
Uchwalona w Kortezach 24 lutego 1932 r., rozwijała ona i doprecyzowywała konstytucyjny przepis cytowanego już art. 43 republikańskiej ustawy zasadniczej ${ }^{53}$.

Analizując stan prawny zaistniały po wprowadzeniu w życie ustawy o małżeństwie cywilnym należy wspomnieć o braku formalnej nowelizacji przez prawodawcę republikańskiego przepisów kodeksu cywilnego w celu zharmonizowania jego treści z Ley del Matrimonio Civil. Trudno odpowiedzieć w sposób ostateczny, czy o braku tej nowelizacji zadecydował stosunkowo szybki upadek Republiki czy też inne powody. Prawdopodobnie dyspozycja zawarta w art. 12 rzeczonej ustawy sprawiała, że nowelizacja taka $\mathrm{w}$ tamtym momencie w praktyce nie wydawała się konieczna. W art. 12 ustawodawca stwierdzał bowiem, że „od momentu wejścia w życie niniejszej ustawy, uznaje się tylko jedną formę małżeństwa, tj. cywilną", którą należy stosować przy zawieraniu małżeństwa zgodnie tylko z tymi przepisami kodeksu, które dotyczą tej właśnie formy ${ }^{54}$.

\section{HISZPANIA POD RZĄDAMI GEN. FRANCO (1939-1975)}

Jeszcze w trakcie wojny domowej (1936-1939) władze nowego państwa podjęły decyzję o powrocie do systemu prawa małżeńskiego, jaki obowiązywał w Hiszpanii przedrepublikańskiej ${ }^{55}$. W tym celu, ustawą z dnia 12 marca 1938 r. ${ }^{56}$ równocześnie uchylono ustawę o małżeństwie cywilnym z dnia 28 czerwca 1932 r. i uznano skutki cywilne małżeństw zawartych wyłącznie w formie kanonicznej w okresie obowiązywania Ley del Matrimonio Civil (od momentu ich zawarcia). Ustawę tę doprecyzowywało

53 Jako że bezpośrednim przedmiotem niniejszego opracowania jest zawarcie małżeństwa, a nie jego rozwiązanie, ustawa ta nie będzie przedmiotem dalszej analizy.

54 De la Hera 1975, 650.

55 Dekretem Ministra Sprawiedliwości z dnia 2 marca 1938 r. (a więc jeszcze w czasie działań wojennych) na terenach znajdujących się pod kontrolą sił ,narodowych” zawieszono obowiązywalność ustawy rozwodowej, a także toczące się w tym czasie na mocy tej ustawy procesy rozwodowe oraz te o separację. Ryguła 2009a, 144.

56 Ley derogando la Ley de matrimonio civil de 28 de junio de 1932 y las disposiciones dictadas para su aplicación, BOE 1938, n. 516 (de 21 de marzo), s. 6353-6354. 
rozporządzenie Ministerstwa Sprawiedliwości z dnia 22 marca 1938 r. ${ }^{57} \mathrm{Za}$ pomocą wspomnianego aktu - w którym to powoływano się na nieuchylony przez prawodawcę republikańskiego art. 42 hiszpańskiego kodeksu cywilnego oraz na fakt uchylenia przez nowe władze ustawy o małżeństwie cywilnym - prawodawca hiszpański powracał do wymogu formalnego oświadczenia dotyczącego niewyznawania religii katolickiej dla osób chcących wstąpić w cywilny związek małżeński. Rozporządzenie nie dookreślało sposobu składania tego oświadczenia, ani tego, co ustawodawca miał na myśli stosując w interpretowanym przepisie kodeksowym wyrażenie „nie wyznają religii katolickiej”.

Właśnie w celu doprecyzowania właściwego rozumienia art. 42 hiszpańskiego kodeksu cywilnego w nowej rzeczywistości społeczno-politycznej Hiszpanii, już po zakończeniu działań wojennych, w rozporządzeniu Ministerstwa Sprawiedliwości z dnia 10 marca $1941 \mathrm{r}^{58}$ dokonano obowiązującej wykładni rzeczonego artykułu. Różnice w rozumieniu i aplikacji wspomnianego przepisu kodeksowego w przeszłości, podkreślano $\mathrm{w}$ rozporządzeniu, wynikały nie tylko z odmiennych interpretacji rzeczonego artykułu w wydawanych w okresie restauracji burbońskiej rozporządzeniach, ale także z faktu wejścia w życie w 1918 r. Kodeksu Prawa Kanonicznego, „stanowiącego część ustawodawstwa hiszpańskiego na mocy dekretu królewskiego z 19 maja 1919 r." Rozporządzenie z 1941 r. wydano więc także w celu koordynacji ustawodawstwa państwowego i kanonicznego w tym, co odnosi się do formy zawarcia małżeństwa.

Tekst rozporządzenia nie tylko przypominał katolikom o obowiązku zawierania małżeństwa zgodnie z przepisami prawa kanonicznego, ale ponadto w interpretacji kodeksowego artykułu zrównywał „niewyznawanie wiary katolickiej" (no profesar la Religión católica) przez daną osobę z jej „akatolickością” (acatolicidad) ${ }^{59}$. Zezwalał bowiem sędziom municypalnym na udzielenie zgody na zawarcie małżeństwa cywilnego tylko tym

57 Orden dictando normas relativas a los expedientes de matrimonio civil que se hallan en tramitación, BOE 1938, n. 520 (de 25 de marzo), s. 6417-6418.

58 Orden de 10 de marzo de 1941 sobre interpretación del artículo 42 del Código Civil, BOE 1941, n. 71 (de 12 de marzo), s. 1775. Na temat wspomnianego rozporządzenia ministerialnego w relacji do prawa kanonicznego zob. Lamas 1941, 143-166.

59 Pod terminem ,akatolik” (acatólico) rozumiano osobę, która nigdy, nawet przez krótki okres, nie należała do Kościoła Katolickiego. Regatillo 1961, 352. 
osobom, które przedstawią dokumenty świadczące o braku przynależności do Kościoła Katolickiego, a jeśli to okazałoby się niemożliwe, zaprzysiężone oświadczenie stwierdzające, iż nigdy nie były one ochrzczone. Do złożenia takiego oświadczenia rozporządzenie ministerialne zobowiązywało obie osoby pragnące wstąpić w związek cywilny. W przeciwieństwie więc do rozporządzenia z 1938 r., które zezwalało na zawarcie małżeństwa cywilnego osobom deklarującym niewyznawanie wiary katolickiej ${ }^{60}$, rozporządzenie z $1941 \mathrm{r}$. zobowiązywało do zawarcia małżeństwa kanonicznego wszystkich ochrzczonych w Kościele Katolickim, niezależnie od aktualnego stanu ich przekonań religijnych i ich aktualnego statusu kanonicznego.

Problemu interpretacyjnego, który to rząd hiszpański jednostronnie starał się uregulować na poziomie rozporządzeń ministerialnych, nie rozwiązał niestety zawarty w 1953 r. konkordat między Stolicą Apostolską i Hiszpanią ${ }^{61}$ W art. 23 wspomnianej umowy międzynarodowej stwierdzano jedynie, że „Państwo hiszpańskie uznaje wszystkie skutki cywilne małżeństwa zawartego według norm prawa kanonicznego". Oprócz wspomnianej gwarancji, w protokole końcowym umowa ta determinowała zakres autonomii małżeństwa kanonicznego w obrocie hiszpańskiego prawa cywilnego. Protokół ten stwierdzał nie tylko, że obecność funkcjonariusza państwowego w czasie ceremonii zawierania związku kanonicznego nie jest warunkiem koniecznym do zaistnienia skutków cywilnych wynikających z zawarcia związku małżeńskiego, ale także, że możliwość wpisu dotyczącego zawarcia tego małżeństwa do właściwego rejestru państwowego - w wypadku, gdyby nie uczyniono tego zaraz po jego zawarciu - istnieje w każdym czasie, nawet po śmierci jednego z małżonków ${ }^{62}$.

Paradoksalnie, pisze A. de la Hera, dyskusja wokół art. 23 konkordatu - który ani nie nowelizował stanu prawnego opartego na rozporządzeniu

60 Osobą deklarująca niewyznawanie wiary katolickiej mogła być zarówno osoba niewierząca i dlatego niechrzczona, jak i osoba ochrzczona w Kościele Katolickim, ale za pomocą deklaracji stwierdzająca aktualny, nieraz chwilowy brak wiary, jak i apostata.

61 Concordato entre España y la Santa Sede, BOE 1953, n. 292 (de 19 de octubre), s. $6230-6234$.

${ }^{62}$ Concordato entre España y la Santa Sede, BOE 1953, n. 292 (de 19 de octubre), Protocolo final, en relación con el artículo XXIII, n. 2-3. 
ministerialnym z 1941 r., ani go nie potwierdzał ${ }^{63}$ - stała się katalizatorem tendencji zmierzającej do zmiany rzeczonego stanu. Tendencja ta znalazła swoje odzwierciedlenie m.in. w orzeczeniu madryckiego trybunału (Audiencia Territorial de Madrid) z dnia 6 czerwca 1955 r. zezwalającego apostatom, „którzy z własnej woli odeszli z Kościoła katolickiego” na zawarcie małżeństwa cywilnego ${ }^{64}$.

Ostatecznie, w wyniku debaty nad rozporządzeniem Ministerstwa Sprawiedliwości z 1941 r., którego interpretacja art. 42 hiszpańskiego kodeksu cywilnego w opinii wielu autorów wydawała się nazbyt restrykcyjna, wprowadzono ustawę z dnia 24 kwietnia $1958 \mathrm{r}^{65}$, na mocy której nie tylko znowelizowano obowiązującą wykładnię art. 42 hiszpańskiego kodeksu cywilnego, ale także dokonano zmian redakcyjnych we wspomnianym oraz innych artykułach kodeksu, regulujących zawieranie małżeństwa w Hiszpanii. Zgodnie z nową redakcją art. 42, „Ustawa uznaje dwie kategorie małżeństwa: kanoniczną i cywilną. Małżeństwo należy zawrzeć zgodnie z formą kanoniczną, kiedy przynajmniej jeden z kontrahentów wyznaje religię katolicką. Zezwala się na zawarcie małżeństwa cywilnego, kiedy udowodni się, że żaden z kontrahentów nie wyznaje religii katolickiej”. Zgodnie z cytowanym artykułem i jego znowelizowaną interpretacją prawodawca zezwalał na zawarcie małżeństwa cywilnego

${ }^{63} \mathrm{~W}$ toczącej się dyskusji na temat właściwego rozumienia art. 23 konkordatu z 1953 r., jedna grupa autorów utrzymywała, że artykuł ten odpowiada w pełni obowiązującemu w Hiszpanii w momencie podpisywania tej umowy stanowi prawnemu (stanowi zgodnemu z rozporządzeniem ministerialnym z 1941 r.). Inni, odwrotnie, argumentowali, że konkordat gwarantuje osobom zawierającym małżeństwo kanoniczne zaistnienie skutków cywilnych, nie determinując równocześnie wymogów co do osób zobowiązanych do zawarcia takiego związku. Zob. m.in. Sancho Rebullida 1955; Espín Cánovas 1956, 31 i n.

64 Pomimo pozostawania w mocy wspomnianego wyżej rozporządzenia z 1941 r., decyzją Generalnej Dyrekcji ds. Rejestrów Państwowych (z dnia 17 grudnia 1954 r.) zezwolono na zawarcie ślubu cywilnego między dwoma protestantami ochrzczonymi w Kościele Katolickim. A. de la Hera pisze wprost, iż decyzja ta, zgodnie z obowiązującym wówczas prawem nie powinna była być wydana. Fundamentem prawym, na który powoływał się autor tego konkretnego aktu administracyjnego był art. 23 konkordatu z 1953 r. Rok później Izba trzecia Sądu Okręgowego w Madrycie wydała przytoczone wyżej orzeczenie z dnia 6 czerwca 1955 r. De la Hera1975, 664-665.

65 Ley de 24 de abril de 1958 por la que se modifican determinados artículos del Código civil, BOE 1958, n. 99 (de 25 de abril), s. 730-738. 
osobom, które - będąc wcześniej ochrzczonymi w Kościele Katolickim w momencie zawierania małżeństwa już do niego nie należały ${ }^{66}$.

\section{HISZPAŃSKA MONARCHIA KONSTYTUCYJNA}

Dzięki transformacji politycznej, jaka dokonała się w Hiszpania po śmierci gen. Franco, prawodawca odszedł w końcu od tworzenia fundamentów ustrojowych państwa z perspektywy „dwóch Hiszpanii”, tj. albo z perspektywy aksjologicznych założeń katolickiej monarchii, albo budowanej na ich negacji laickiej republiki ${ }^{67}$. Wspomniana neutralność państwa w tzw. „kwestii religijnej” pozwoliła z kolei na wprowadzenie w życie przepisów prawa małżeńskiego wpisanego w system prawa państwa neutralnego światopoglądowo.

W art. 1 hiszpańskiej ustawy zasadniczej z 1978 r. ustrojodawca zapewnia, że państwo „chroni jako najważniejsze wartości swego porządku prawnego wolność [...] równość”, a w art. 9 stwierdza, że „do władz publicznych należy kształtowanie takich warunków, aby wolność i równość poszczególnych osób oraz grup [...] mogły być w sposób rzeczywisty i efektywny realizowane" ${ }^{68}$. Aplikując tę konstytucyjną gwarancję do wolności na płaszczyźnie religijnej, w art. 16 hiszpańskiej ustawy zasadniczej stwierdza się: „1. Poszczególnym osobom oraz wspólnotom gwarantuje się wolność religijną i kultu, a także wolność w wyznawaniu jakiejkolwiek wiary czy ideologii. Ich jedynym ograniczeniem, w zewnętrznych

66 Zgodnie z obowiązującym wówczas prawem kanonicznym, kan. 1099 KPK z 1917 r. zobowiązywał apostatów do zawarcia małżeństwa zgodnie z formą kanoniczną. Codex Iuris Canonici Pii X Pontificis Maximi iussu digestus Benedicti Papae XV auctoritate promulgatus, AAS 9 (1917), cz. II.

${ }^{67}$ Było to możliwe dzięki temu, że proces przemian politycznych rozpoczął się od zmian na płaszczyźnie relacji państwo-Kościół. Na rok przed wyborami do parlamentu mającego uchwalić nową konstytucję demokratycznej Hiszpanii, podpisana została tzw. umowa podstawowa (Acuerdo básico) między Stolicą Apostolską i Hiszpanią, w której obaj sygnatariusze deklarowali w preambule wolę ułożenia wzajemnych stosunków na zasadzie „niezależności obu stron we właściwym sobie zakresie”. Acuerdo entre La Santa Sede y el Estado español, BOE 1976, n. 230 (de 24 de septiembre), s. 18664-18665.

68 Constitución española, BOE 1978, n. 311.1 (de 29 de diciembre), s. 29315-29339. 
przejawach, jest porządek publiczny chroniony prawem. 2. Nikt nie może być zmuszany do składania deklaracji na temat swojej religii, przekonań czy ideologii. 3. Żadne wyznanie nie będzie miało charakteru wyznania państwowego". Z kolei w odniesieniu do małżeństwa, w art. 32 konstytucji prawodawca stwierdza: „1. Mężczyzna i kobieta mają prawo zawrzeć związek małżeński przy poszanowaniu pełnej równości prawnej. 2. Ustawa określi formy małżeństwa, wiek i zdolność do jego zawarcia, prawa i obowiązki małżonków, przyczyny separacji i rozwiązania oraz ich skutki"69.

Obowiązujące obecnie w Hiszpanii prawo przewiduje cywilną i religijną formę zawarcia małżeństwa. Warto w tym miejscu zwrócić uwagę - pozostawiając dokładniejszą analizę tego zagadnienia na inną okazję - na zmianę terminologii stosowanej w przepisach kodeksu cywilnego odnośnie do małżeństwa. O ile w całej wcześniejszej historii prawodawca hiszpański rozróżniał pomiędzy kanoniczną i cywilną formą zawarcia związku oraz kanonicznym i cywilnym małżeństwem, w pozostającym obecnie w mocy tekście kodeksu mówi on o religijnej i cywilnej formie zawarcia związku ${ }^{70}$. Wspomnianą dwoistość formy zawarcia małżeństwa hiszpański kodeks cywilny przewidywał zarówno przed, jak i po wejściu w życie przywołanej wyżej ustawy 15/2015 o jurysdykcji w postępowaniu nieprocesowym (z dnia 2 lipca 2015 r.). W znowelizowanym wspomnianą

69 Biorąc pod uwagę temat niniejszego opracowania należy zwrócić uwagę na terminologię, jaką posługuje się prawodawca hiszpański używający pojęcia formy. Terminu tego zarówno w prawodawstwie, jak i doktrynie prawa hiszpańskiego używa się nie tylko w odniesieniu do formy zawarcia związku małżeńskiego, ale także w odniesieniu do różnorodności form samej instytucji małżeństwa. O powyższym, dwojakim znaczeniu terminu „forma” pisze m.in. Lalaguna 2000, 3995-4007. W niniejszym tekście, z oczywistych względów, termin forma del matrimonio używany jest w odniesieniu do zawierania związku małżeńskiego.

70 Jeszcze w ustawie z dnia 24 kwietnia 1958 r., nowelizującej treść przepisów kodeksu cywilnego, w art. 42 mowa jest o „dwóch kategoriach małżeństwa: kanonicznej i cywilnej” (dos clases de matrimonio: el canónico y el civil). W ustawie z dnia 7 lipca 1981 r., już $\mathrm{w}$ art. 49 kodeksu, mowa jest o dwóch formach zawarcia małżeństwa: cywilnej i religijnej. Zob. Ley de 24 de abril de 1958 por la que se modifican determinados artículos del Código civil, BOE 1958, n. 99 (de 25 de abril), s. 730-738; Ley 30/1981, de 7 de julio, por la que se modifica la regulación del matrimonio en el Código Civil y se determina el procedimiento a seguir en las causas de nulidad, separación y divorcio, BOE 1981, n. 172 (de 20 de julio), s. 16457-16462. 
Ley de la Jurisdicción Voluntaria art. 49 hiszpańskiego kodeksu cywilnego czytamy: „Każdy Hiszpan może zawrzeć małżeństwo w Hiszpanii i poza nią: 1 . Zgodnie $z$ formą regulowaną tym kodeksem. 2. Zgodnie $\mathrm{z}$ formą religijną przewidzianą prawem" "71.

Z kolei art. 60 hiszpańskiego kodeksu cywilnego - również znowelizowany wspomnianą Ley de la Jurisdicción Voluntaria - dookreśla przepis cytowanego art. 49 ust. 2, stwierdzając: „1. Małżeństwo zawierane zgodnie $\mathrm{z}$ normami prawa kanonicznego albo w którejś z form religijnych przewidzianych w umowach o współpracy między państwem a wyznaniami religijnymi powoduje zaistnienie skutków cywilnych. 2. Tak samo, uznaje się skutki cywilne w odniesieniu do małżeństw zawieranych w formie religijnej właściwej tym Kościołom, wyznaniom, wspólnotom religijnym czy ich federacjom, które, wpisane do rejestru związków wyznaniowych, uznane zostały za zakorzenione w Hiszpanii”. W celu zaistnienia skutków cywilnych małżeństw religijnych zawieranych w ramach związków wyznaniowych, które nie podpisały umów o współpracy z państwem ${ }^{72}$, zgodnie z cytowanym art. 60 ust. 2 hiszpańskiego kodeksu cywilnego należy: a) przed ceremonią zawarcia małżeństwa uzyskać właściwe zaświadczenie stwierdzające zdolność do jego zawarcia na forum prawa cywilnego, b) w czasie

71 Treść znowelizowanego art. 49 hiszpańskiego kodeksu cywilnego zawarta jest w pierwszej dyspozycji końcowej Ley de Jurisdicción Voluntaria (disposición final 1.3). Zob. powołana wyżej Ley 15/2015, de 2 de julio, de la Jurisdicción Voluntaria, s. 54068-54201. Treść wspomnianych przepisów przed nowelizacją w: Real Decreto de 24 de julio de 1889 por el que se publica el Código Civil, „Gaceta de Madrid” 1889, n. 206 (de 25 de julio), s. 246-259.

72 Dotychczas umowy o współpracy z państwem hiszpańskim zawarły: Federacja Ewangelickich Związków Wyznaniowych w Hiszpanii, Federacja Wspólnot Izraelskich w Hiszpanii i Komisja Islamska w Hiszpanii. Zob. Ley 24/1992, de 10 de noviembre, por la que se aprueba el Acuerdo de Cooperación del Estado con la Federación de Entidades Religiosas Evangélicas de España, BOE 1992, n. 272 (de 12 de noviembre), s. 38209-38211; Ley 25/1992, de 10 de noviembre, por la que se aprueba el Acuerdo de Cooperación del Estado con la Federación de Comunidades Israelitas de España, BOE 1992, n. 272 (de 12 de noviembre), s. 38211-38214; Ley 26/1992, de 10 de noviembre, por la que se aprueba el Acuerdo de Cooperación del Estado con la Comisión Islámica de España, BOE 1992, n. 272 (de 12 de noviembre), s. 38214-38217. 
ceremonii w sposób wolny wyrazić zgodę małżeńską wobec właściwie akredytowanego ministra kultu i dwóch pełnoletnich świadków ${ }^{73}$.

W powyższy sposób prawodawca hiszpański wyraźnie poszerza w stosunku do wcześniejszych regulacji grupę związków wyznaniowych, których wierni mogą zawrzeć małżeństwo zgodnie z formą religijną temu związkowi właściwą. Warunkiem sine que non uznania rzeczonej formy za podstawę zaistnienia skutków cywilnych jest jednak fakt wpisania danej wspólnoty religijnej do Rejestru Związków Wyznaniowych. W art. 59 hiszpańskiego kodeksu cywilnego prawodawca stwierdza bowiem: ,zgoda małżeńska będzie mogła być wyrażona w formie przewidzianej przez zarejestrowany związek wyznaniowy, w sposób uzgodniony z państwem, a wypadku braku tego [uzgodnienia, w formie] dopuszczonej przez ustawodawstwo państwowe”. To poszerzenie zakresu możliwości zawarcia małżeństwa w formie religijnej, zawarte w ustawie o jurysdykcji w postępowaniu nieprocesowym z dnia 2 lipca 2015 r., hiszpański prawodawca argumentuje pluralizmem religijnym, który istnieje obecnie W społeczeństwie hiszpańskim ${ }^{74}$. Sugeruje tym samym, że wcześniej niejednokrotnie trudno mu było taki pluralizm dostrzec i z perspektywy wspomnianego pluralizmu kształtować ustawodawstwo państwowe.

Będąc świadom wspomnianego pluralizmu, prawodawca korzysta z instrumentów normatywnych wypracowanych i aplikowanych wcześniej w stosunku do zakorzenionych w rzeczywistości społecznej kościołów i innych związków wyznaniowych. Pozwala to - zauważa C. Berenguer, mając na myśli także prawodawcę hiszpańskiego - na zachowanie tożsamości religijno-prawnej instytucji małżeństwa w ramach tych wyznań, które wpisały się w tradycję prawną konkretnego państwa ${ }^{75}$. Umożliwia ponadto aplikację wypracowanych wcześniej rozwiązań do tych

73 Treść znowelizowanego art. 60 hiszpańskiego kodeksu cywilnego zawarta jest w pierwszej dyspozycji końcowej Ley de Jurisdicción Voluntaria (disposición final 1.12).

74 Ley de Jurisdicción Voluntaria (preámbulo XI).

75 Pisząc przede wszystkim o możliwości zawarcia małżeństwa $\mathrm{w}$ formie religijnej w Anglii C. Berenguer nawiązuje do prawa hiszpańskiego: ,en dicho país tanto el matrimonio anglicano como el judío y el cuáquero, gozan de un tratamiento particular que se explica básicamente por razones de orden histórico, de forma similar a lo que ocurre en España con el matrimonio canónico". Pisząc to odwołuje się do: Probert 2011, 78 i nn. Zob. Berenguer Albaladejo 2015, 89-90. 
wyznań, które z różnych powodów nie współtworzyły w równym stopniu rzeczonej tradycji, ale obecnie współtworzą społeczną rzeczywistość pluralizmu religijnego.

\section{BIBLIOGRAFIA}

Acuña Guirola, Sara. 1973. „La forma del matrimonio hasta el Decreto Ne temeré”. Ius Canonicum 13: 137-190.

Bączkowicz, Franciszek. 1958. Prawo kanoniczne. Podręcznik dla duchowieństwa, T. 2. Kraków: Wydawnictwo Św. Krzyża w Opolu.

Berenguer Albaladejo, Cristina. 2015. „Los matrimonios en forma religiosa no canónica: celebración e inscripción en el registro civil de acuerdo con las reformas operadas por la Ley 15/2015, de 2 de julio, de la jurisdicción voluntaria". Derecho Privado y Constitución 29: 83-131.

Bernárdez Cantón, Alberto. 1971. Curso de Derecho Matrimonial Canónico. Madrid: Ed. Tecnos.

De Jorge García Reyes, Juan A. 1986. El matrimonio de las minorías religiosas en el Derecho español. Madrid: Tecnos.

De la Hera, Alberto. 1975. „Matrimonio civil y revisión del concordato (Cuestiones en torno al artículo 42 del Código civil)". Anuario de Derecho Civil 28: 639-682.

Dohnalik, Jan. 2018. „Forma kanoniczna zawarcia małżeństwa - spojrzenie historyczne i postulat reformy". Annales Canonici 14/II: 183-202.

Espín Cánovas, Diego. 1956. Manual de Derecho Civil Español, T. 4. Madrid: Ed. Revista D. Privado.

Fernández Collado, Ángel. 2007. Historia de la Iglesia en España. Edad moderna. Toledo: Instituto Teológico San Ildefonso.

Fuenmayor, Amadeo de. 1963. „El matrimonio y el Concordato español”. Ius Canonicum 5-6/III: 251-418.

Hernández Fuentes, Miguel-Ángel. 2016. En defensa de los sagrados intereses. Historia religiosa de la Diócesis de Zamora durante la restauración (1875-1914). Salamanca: Ed. Universidad Salamanca.

Krukowski, Józef. 2000. Kościót i państwo. Podstawy relacji prawnych. Lublin: Redakcja Wydawnictw KUL.

Lalaguna Domínguez, Enrique. 2000. „Competencia del Estado sobre relaciones jurídico-civiles relativas a las formas de matrimonio". Boletín del Ministerio de Justicia 1883: 3995-4007. 
Lamas, Ramón. 1941. „La orden de 10 de marzo de 1941 sobre interpretación del artículo 42 del Código y el Derecho canónico, histórico y vigente". Revista de la Facultad de Derecho de Madrid 4-5: 143-166.

Martí, José M., David García-Pardo, Santiago Catalá. 2003. El matrimonio religioso en el Derecho español. Albacete: Popular Libros.

Navarro Valls, Rafael. 1972. Divorcio: orden público y matrimonio canónico. Madrid: Ed. Montecorvo.

Payne, Stanley G. 2006. El catolicismo español, Barcelona: Ed. Planeta.

Pelczar, Józef Sebastian. 1898. Prawo matżeńskie katolickie z uwzględnieniem prawa cywilnego obowiazujacego w Austryi, Prusach $i$ w Królestwie Polskiem. Kraków: Drukarnia Uniwersytetu Jagiellońskiego.

Pérez Mier, Laureano. 1940. Iglesia y Estado nuevo. Madrid: Ed. Fax.

Probert, Rebecca. 2011. Family Law in England and Wales. Alphen aan den Rijn: Wolters Kluwer.

Regatillo, Eduardo. 1961. El concordato español de 1953. Santander: Sal Terrae.

Rodríguez Chacón, Rafael. 1994. „El matrimonio religioso no católico en Derecho español”. Anuario de Derecho Eclesiástico del Estado 10: 369-430.

Ryguła, Piotr. 2009a. „Skutki cywilne zawarcia małżeństwa kanonicznego w hiszpańskim systemie prawnym”. W: Zawieranie malżenstwa w różnych systemach prawnych, religiach i kulturach, red. Ryszard Sztychmiler, 139-157. Olsztyn: Wydawnictwo Uniwersytetu Warmińsko-Mazurskiego.

Ryguła, Piotr. 2009b. Wolność religijna w Hiszpanii na tle przemian spoleczno-politycznych w latach 1931-1992. Katowice: Wydawnictwo Uniwersytetu Śląskiego.

Sánchez Román, Felipe. 1912. Estudios de Derecho civil. T. V: Derecho de Familia. Madrid: Analecta.

Sancho Rebullida, Francisco. 1955. Las formalidades civiles del matrimonio canónico. Madrid: Ed. Revista D. Privado.

Tunia, Anna. 2008. „Kształtowanie się kanonicznej formy zawarcia małżeństwa”. Roczniki Nauk Prawnych 18/1: 129-159. 